\title{
PENINGKATA HASIL BELAJAR SISWA TUNA DAKSA KELAS VIII DENGAN ALAT PERAGA MODEL PENCERNAAN PADA SISTEM PENCERNAAN MANUSIA DI SMPLB NEGERI PEMBINA ACEH TAMIANG TP 20152016
}

\author{
Millati \\ Guru SLB Negeri Pembina Aceh tamiang \\ millatikamal@yahoo.co.id
}

\begin{abstract}
Abstrak
Artikel ini merupakan hasil dari penelitian tindakan kelas yang berjudul "Peningkatan Hasil Belajar Siswa Tuna Daksa Kelas VIII Dengan Alat Peraga Model Pencernaan Pada Materi Sistem Pencernaan Manusia di SMPLB Negeri Pembina Aceh Tamiang TP 2015/2017" ini mengangkat masalah bagaimanakah kemampuan siswa kelas VIII Tuna Daksa SMPLB Negeri Pembina Aceh Tamiang menyelesaikan pembelajaran pada materi sistem pencernaan. Penelitian ini bertujuan meningkatkan hasil belajar siswa kelas VIII tuna daksa SMPLB Negeri Pembina Aceh Tamiang. Subjek penelitian adalah siswa kelas VIII tuna daksa SMPLB Negeri Pembina Negeri Aceh Tamiang tahun pelajaran 2015/2016 yang berjumlah 1 siswa. Metode yang digunakan adalah dengan model menggunakan alat peraga pencernaan. Pengumpulan data dilakukan dengan teknik tes dan pengolahan data menggunakan statistik sederhana dalam bentuk penghitungan nilai siklus. Acuan yang digunakan sebagai parameter adalah hasil nilai belajar dengan ketuntasan minimal yaitu nilai 65. Hasil penelitian menunjukkan perubahan secara individual.
\end{abstract}

Kata Kunci: Hasil Belajar, Alat Peraga, Parameter, Ketuntasan Minimal, Kemampuan Siswa

\section{PENDAHULUAN}

Pada Undang Undang Dasar 1945 pasal 31 Ayat 1 dan 2 menyatakan : 1.Setiap warga negara berhak mendapat pengajaran, 2 Pemerintah mengusahakan dan menyelenggarakan satu sistem pengajaran nasional yang diatur dengan undang undang. Jadi pendidikan merupakan hak yang harus diterima oleh setiap warga negara dan pemerintah yang bertanggung jawab dalam mencerdaskan kehidupan bangsa melalui guru pada umumnya, juga guru pada pendidikan khusus

Kelemahan dalam memberikan informasi kepada siswa seringkali terjadi pada saat pelaksanaan proses pembelajaran. Seharusnya melalui proses pembelajaran siswa dapat mengembangkan pengetahuan, keterampilan atau sikap baru melalui interaksi dengan informasi dan lingkungan. Oleh karena itu untuk merancang dan menyusun pengajaran melibatkan banyak pertimbangan, tidak hanya apa yang akan dipelajari siswa, tetapi juga bagaimana siswa dilibatkan dalam proses pembelajaran dan mengimplementasikan pelajaran dalam kehidupan sehari hari

Hambatan dalam melaksanakan proses pembelajaran di SMPLB khususnya siswa tuna daksa dapat dipengaruhi oleh beberapa faktor yaitu: siswa cepat bosan bila hanya membaca buku,tidak mampu memikirkan hal hal yang rumit,lebih senang melakukan bekerjaan dari pada berfikir.

Selain itu dalam menyampaikan materi di sekolah tidak semua tersedianya alat bantu pembelajaran ,misalnya alat peraga,,oleh karna itu perlu alat peraga dalam penyampaian materi.
Kesesuaian penggunaan alat peraga dengan materi yang ingin disampaikan. harus benar-benar dipertimbangkan. Tujuannya adalah materi pelajaran yang ingin kita sampaikan dapat diterima dengan jelas dan dimengerti oleh siswa.

Pada materi Sistem Pencernaan Makanan adalah mata pelajaran IPA sering menjadi hambatan sehingga proses pembelajaran tidak dapat berjalan dengan baik. Materi ini merupakan materi yang cukup sulit untuk siswa tuna daksa.Hal ini terbukti dari hasil tes awal yang tidak mendapat angka ketuntasan

Dari hasil diskusi dengan teman sejawat di peroleh kesimpulan sebagai penyebab rendahnya hasil belajar di antaranya:

1. Guru belum menggunakan alat peraga pembelajaran yang dapat mengaktifkan siswa dalam pembelajaran

2. Diharapkan guru merancang dan membuat alat peraga pembelajaran yang efektif .

3. Siswa pasif dalam mengikuti kegiatan pembelajaran.

Berdasarkan dari penyebab rendahnya hasil belajar pada pembelajaran

Pada materi sistem pencernaan makanan, maka penulis ingin mencoba memperbaiki kualitas dan hasil belajar siswa dengan menggunakan Alat peraga Model Pencernaan yang dibuat oleh guru melalui MGMP dan siswa tuna daksa untuk meningkatkan hasil belajar dan aktifitas belajar siswa.

Berdasarkan uraian di atas maka rumusan masalah dalam penelitian ini sebagai berikut apakah dengan menggunakan alat peraga model pencernaan 
dapat meningkatkan hasil belajar siswa pada materi sistem pencernaan di kelas VIII Tuna Daksa SMPLB Negeri Pembina Aceh Tamiang?

Berdasarkan rumusan masalah,maka tujuan dalam penelitian ini adalah sebagai berikut :

1. Untuk meningkatkan hasil belajar siswa dengan menggunakan alat peraga model pencernaan pada materi sistem pencernaan di kelas VIII Tuna Daksa SMPLB Negeri Pembina Aceh Tamiang

2. Untuk meningkatkan aktifitas dengan menggunakan alat peraga model pencernaan pada materi sistem pencernaan di kelasVIII Tuna Daksa SMPLB Negeri Pembina Aceh Tamiang .

3. Untuk meningkatkan aktitas guru dalam mengelola kelas

Hasil penelitian ini diharapkan dapat bermanfaat bagi:

1. Guru

a. Meningkatkan kualitas pembelajaran

b. Mencipkan suasana pembelajaran yang menarik, gembira dan menyenangkan bagi siswa.

\section{Siswa}

a. Meningkatkan hasil belajar siswa.

b. Meningkatkan aktivitas siswa dalam pembelajaran

c. Meningkatkan pemahaman siswa terhadap materi Sistem Pencernaan

\section{Peneliti}

Hasil penelitian ini dapat di gunakan untuk kelengkapan kenaikan golongan ke IV C

\section{Hakekat Belajar}

Pembelajaran yang identik dengan kata "mengajar" yang berarti petunjuk yang diberikan kepada orang supaya diketahui atau dituruti yang harus melalui proses, pembuatan, cara mengajar atau mengajarkan sehingga anak didik mau belajar. Pembelajaran merupakan suatu kombinasi yang tersusun, meliputi unsur-unsur manusiawi, materiel, fasilitas, perlengkapan dan prosedur yang saling mempengaruhi untuk mencapai tujuan pembelajaran

Menurut Gagne dan Briggs (Hamzah. 2011) “ pembelajaran adalah suatu system yang bertujuan untuk membantu proses belajar siswa, yang berisi serangkaian peristiwa yang dirancang, disusun sedemikian rupa untuk mempengaruhi dan mendukung terjadinya proses belajar siswa yang bersifat internal". Sepintas pengertian mengajar hampir sama dengan pembelajaran, namun pada dasarnya berbeda. Dalam pembelajaran kondisi atau situasi yang memungkinkan terjadinya proses belajar harus dirancang dan dipertimbangkan lebih dahulu oleh perancang atau guru. Dalam keseharian disekolah-sekolah istilah pembelajaran atau proses belajar sering dipahami sama dengan proses belajar mengajar dimana didalamnya ada interaksi guru dan siswa dan antara siswa untuk mencapai suatau tujuan yaitu terjadinya perubahan sikap dan tingkah laku siswa. Apa yang dipahami guru itu sesuai dengan pengertian yang diuraikan dalam buku pedoman kurikulum 1994 ( dalam B. Hamzah, 2011 : 145 ). Menurut Arief (dalan B. Hamzah. 2011 : 145 ) " fungsi belajar dilakukan oleh komponen siswa, fungsi pembelajaran dan penilaian (yang terbagi dalam pengelolan belajar dan sumber belajar) dilakukan oleh sesuatu di luar diri siswa". Pembelajaran mengubah masukan berupa siswa yang belum terdidik menjadi siswa yang terdidik. Sebenarnya belajar dapat saja terjadi tanpa pembelajaran, namun hasil belajar akan tampak lebih jelas dari suatu pembelajaran. Pembelajaran yang efektif ditandai dengan berlangsungnya proses belajar dalam diri siswa. Seseorang dikatakan telah mengalami proses belajar apa bila dalam dirinya terjadi perubahan tingkah laku dari tidak tahu menjadi tahu, dari tidak bisa menjadi bisa. Dalam pembelajaran hasil belajar dapat dilihat langsung. Oleh karena itu, agar kemampuan siswa dapat dikontrol dan berkembang semaksimal mungkin dalam proses belajar dikelas maka program pembelajaran harus dirancang telebih dahulu oleh para guru dengan memperhatikan berbagai prinsip-prinsip pembelajaran yang telah diuji keunggulannya.

Pada hakekatnya belajar adalah perubahan tingkah laku atau penampilan, dengan serangkaian kegiatan, misalnya membaca, mengamati, mendengarkan dan meniru. Belajar akan membawa suatu perubahan pada individu yang belajar. Perubahan itu tidak hanya mengenai jumlah pengetahuan, melainkan juga bentuk kecakapan, kebiasaan, sikap, pengertian, penghargaan, minat, penyesuaian diri dan sebagainya Nasution.(dalam B.Hamzah.2011:141)

\section{Permasalahan Anak Tunadaksa}

Tuna daksa adalah anak yang mengalami kelainan atau cacat yang menetap pada anggota gerak seperti tulang, sendi, maupun otot. Menurut Samuel A kirk(1986) yang dialihbahasakan oleh Moh. Amin dan Ina Yusuf kusumah (1991:3) mengemukakan bahwa seseorang dikatakan anak tunadaksa jika kondisi fisik atau kesehatan mengganggu kemampuan - kemampuan anak untuk berperan aktif dalam kegiatan sehari - hari, sekolah atau rumah. Beberapa ciri anak tunadaksa yaitu terrdapat bagian anggota gerak yang tidak lengkap/tidak sempurna/lebih kecil dari biasa, mengalami kesulitan dalam gerakan.

Dari beberapa ciri tersebut anak tunadaksa pasti memiliki masalah, baik dalam fisik, phsikis maupun sosialnya. Beberapa masalah yang terjadi pada anak tunadaksa yaitu:

\section{Fisik}

Masalah fisik yang terjadi pada anak tunadaksa dapat berupa kelumpuhan anggota gerak atas, bawah, atau pada otot-otot penegak tulang punggung yang bisa terjadi sebagian atau keseluruhan. Masalah lainnya yaitu anggota gerak yang lumpuh lebih pendek dari yang tidak lumpuh, kaku sendi (kontraktur) yaitu sendi tidak dapat digerakkan, ditekuk atau diluruskan sebagian atau 
seluruhnya, ada pula terjadi perubahan bentuk pada panggul dan tulang punggung. Dan dikarenakan adanya masalah tersebut terjadi gangguan pada fungsi mobilisasi, mulai dari gangguan berguling, merangkak, duduk, berdiri, berjalan, meraih dan memegang atau menggenggam.

\section{Psikis}

Ditinjau dari aspek psikologis anak tunadaksa cenderung merasa apatis, malu, rendah diri, sensitif dan kadang-kadang pula muncul sikap egois terhadap lingkungannya yang disebabkan oleh perkembangan dan pembentukan pribadi yang kurang didukung oleh lingkungan sekitar. Keadaan seperti ini mempengaruhi kemampuan dalam hal sosialisasi dan interaksi sosial terhadap lingkungan sekitarnya atau dalam pergaulan sehari-harinya.

3. Sosial

Reaksi masyarakat terhadap kelainan ATD sangat bervariasi, pada umumnya lebih banyak yang cenderung bernada negatife.Reaksi masyarakat yang negatife ini sudah tentu dipengaruhi oleh pandangan mereka atau bagaimana mereka menilai ATD.

\section{Kebutuhan Anak Tunadaksa}

Anak tunadaksa walaupun memiliki kekurangan dan hambatan, namun mereka seperti anak-anak pada umumnya yang memiliki kebutuhan yang harus dipenuhi. Perbedaannya yaitu kebutuhan mereka lebih mengacu pada masalah yang dialami anak. Kebutuhan anak tunadaksa antara lain:

1. Kebutuhan Komunikasi

Kebutuhan komunikasi secara lisan, tulisan, maupun menggunakan isyarat merupakan prioritas utama dalam memenuhi kebutuhan anak tunadaksa. Untuk hal ini diperlukan pelatihan dari ahli terapi bicara agar anak tunadaksa dapat berkomunikasi dengan orang lain.

2. Kebutuhan Mobilisasi

Kebutuhan mobilisasi meliputi serangkaian gerakan dari berguling, telungkup, merangkak, duduk, berdiri, dan berjalan menempuh jarak tertentu, dan berpindah tempat.

3. Kebutuhan Sosial

Kebutuhan sosial berupa sikap dan perhatian dari keluarga dan lingkungan terhadap anak tunadaksa yang dapat mendorong yang bersangkutan untuk berusaha meningkatkan kemampuannya.

4. Kebutuhan Psikologis

Efek dari ketunadaksaan kadang menimbulkan sikap yang berlebihan pada keluarga dan juga trauma phikis yang dialami seorang tunadaksa. Konsltasi dengan seorang psikolog merupakan usaha untuk mengubah sikap tersebut.

5. Kebutuhan Pendidikan

Bagi anak tunadaksa yang memiliki kemampuan mengikuti pendidikan, penyaluruan ke pendidikan umum atau khusus merupakan usaha memenuhi kebutuhan akan pendidikan.

\section{Pengertian Media}

Menurut Heinich dkk (1996), media (jamak)/medium (tunggal) secara umum adalah saluran komunikasi, yaitu segala sesuatu yang membawa informasi dari sumber informasi untuk disampaikan kepada penerima pesan.

Tujuan penggunaan media secara umum adalah untuk memfasilitasi komunikasi. Dan tujuan penggunaan media pembelajaran antara lain:

1) Meningkatkan kualitas dan efektivitas pembelajaran,

2) Memudahkan guru dalam melaksanakan pembelajaran,

3) Memberikan arahan tentang tujuan yang akan dicapai

4) Menyediakan evaluasi mandiri,

5) Memberi rangsangan kepada guru untuk kreatif,

6) Menyampaikan materi pembelajaran,

7) Membantu pebelajar yang memiliki kekhususan tertentu.

\section{Materi Pembelajaran \\ Sistem Pencernaan pada Manusia}

Alat pencernaan terdiri dari Mulut, Kerongkongan Lambung, Usus Halus, Usus Besar dan Anus.

Saluran pencernaan adalah saluran yang kontinyu berupa tabung yang dikelilingi otot. Saluran pencernaan mencerna makanan, memecah nya menjadi bagian yang lebih kecil dan menyerap bagian tersebut menuju pembuluh darah. Organ-organ yang termasuk di dalam nya adalah : mulut, kerongkongan, lambung, usus halus serta usus besar dan anus

\section{Rongga Mulut}

Dilakukan pencernaan secara mekanik oleh gigi dan kimiawi oleh ludah yang dihasilkan Kelenjar Parotis, Submandibularis dan Sublingualis yang mengandung enzim Amilase (Ptyalin).

\section{Lambung}

Dilakukan secara mekanik dan kimiawi,

1. Renin yaitu enzim yang mampu menggumpalkan Kasein (sejenis protein) dalam susu.

2. Pepsin untuk memecah protein menjadi pepton

3. Asam Lambung ( $\mathrm{HCl})$. Fungsi HCI Lambung :

a.Merangsang keluamya sekretin

b.Mengaktifkan Pepsinogen menjadi Pepsin

c. Desinfektan

d.Merangsang keluarnya hormon Kolesistokinin yang berfungsi merangsang empdu mengeluarkan getahnya

\section{Usus Halus}

Di dalam Duodenum terdapat getah pankreas (bersifat basa) yang mengandung Steapsin (Lipase), Amilase dan Tripsinogen yaitu:

a. Lipase mengubah lemak menjadi asam lemak dan gliserol

b. Amilase mengubah amylum menjadi glukosa

c. Tripsin megubah pepton mejadi asam amino 
d. Tripsinogen berubah menjadi tripsin oleh Enterokinase.

Usus halus terdiri dari tiga bagian yakni:

a. Duodenum (Usus 12 Jari)

b. Bermuara enzim pencerna dari pankreas Dan empedu dari hati

c. Yeyenum (Usus Kosong)

d. Tidak ada pencernaan secara kimia hanya lewat saja

e. Illeum (usus penyerapan)

f. Terjadi pencernaan dan penyerapan. Didalam illeum terdapat pembuluh darah dan pembuluh kill.

\section{Usus Besar}

Usus besar merupakan tempat bermuaranya usus halus. Daerah persambungan antara usus besar dan usus halus disebut sekum (usus buntu). Pada ujung sekum terdapat umbai cacing atau apendiks. Di dalam usus besar terdapat penyerapan air pada ampas makanan. Selanjutnya, ampas makanan dibusukkan oleh bakteri menjadi tinja.

\section{Anus}

Tinja disimpan di dalam rektum sampai waktunya dikeluarkan. Saat rektum berkontraksi akan terjadi defekasi, yaitu proses pengeluaran tinja melalui anus.

\section{Proses pencernaan}

Proses pencernaan dibantu oleh enzim yang berfungsi mempercepat proses pencernaan. Makanan yang masuk kedalam mulut dikunyah oleh gigi dibantu oleh enzim ptialin yang terkandung dalam air liur. Kemudian makanan masuk kedalam lambung melalui kerongkongan. Didalam lambung zat makanan dibantun oleh getah lambung diurai menjadi sari makanan yang diserap oleh usus halus. Kemudian diteruskan oleh darah sebagai sistem transpot untuk di edarkan ke seluruh tubuh.

Sedangkan sisa pencernaan diteruskan ke usus besar dan dikeluarkan melalui anus.

\section{Hakekat Pembelajaran Sains Di SMP}

Biologi sebagai mata pelajaran Sains di SMP bertujuan untuk memahami konsep IPA dan saling keterkaitannya, mengembangkan daya nalar untuk memecahkan masalah yang dihadapi dalam kehidupan sehari-hari dan mengembangkan keterampilan proses untuk memperoleh konsep IPA dan menumbuhkan nilai dan sikap ilmiah untuk menghasilkan karya teknologi sederhana yang berkaitan dengan kebutuhan manusia. Siswa dalam mempelajari IPA diharapkan memiliki keterampilan dasar yang mendukung kegiatannya diantaranya: mengamati, menggolongkan, menerapkan konsep atau prinsip, menafsirkan, menggunakan alat dan bahan, merencanakan percobaan, berkomunikasi, berhipotesis, dan mengajukan pertanyaan. (Wigata.2013)

\section{Hasil Belajar}

Memberikan penilaian terhadap hasil belajar siswa merupakan kewajiban seorang guru dan mutlak di lakukan.Dikatakan mutlak bagi setiap guru karena pada akhirnya guru dapat memberikan informasi kepada siswa atau lembaga.Bagai mana dan sampai dimana penguasaan dan keterampilan yang telah dicapai siswanya? Menurut pendapat W.J Kripsin dan Feldusen (Hamzzah. 2011) evaluasi adalah satu-satunya cara untuk menentukan ketepatan dalam pembelajaran dan keberhasilan. Dengan demikian dapat dikatakan indikator pembelajaran efektif dapat diketahui dari hasil belajar siswa yang baik.Petunjuk keberhasilan belajar siswa dapat dilihat bahwa siswa tersebut menguasai materi pelajaran yang diberikan.Namun kemampuan siswa yang bervariasi menyebabkan tidak semua siswa dapat menguasai secara tuntas. Menurut Carol (Hamzah. 2011) Kunci pokok untuk memperoleh ukuran data dan hasil belajar adalah dengan menetapkan indikator (petunjuk adanya prestasi tertentu) dikaitkan dengan prestasi yang akan di ukur. Sedangkan menurut pendapat Murshel (Hamzah, 2011) indikator pembelajaran efektif adalah hasil belajar yang tahan lama dan siswa dapat menggunakannya dalam kehidupan.

\section{Alat Peraga \\ Pengertian Alat Peraga}

Alat peraga adalah suatu alat yang dapat diserap oleh mata dan telinga dengan tujuan membantu guru agar proses belajar mengajar siswa lebih efektif dan efisien (Sudjana, 2002).

Alat peraga dalam mengajar memegang peranan penting sebagai alat Bantu untuk menciptakan proses belajar mengajar yang efektif. Proses belajar mengajar ditandai dengan adanya beberapa unsur antara lain tujuan, bahan, metode dan alat, serta evaluasi. Unsur metode dan alat merupakan unsur yang tidak bisa dilepaskan dari unsur lainnya yang berfungsi sebagai cara atau teknik untuk mengantarkan sebagai bahan pelajaran agar sampai tujuan. Dalam pencapain tersebut, peranan alat Bantu atau alat peraga memegang peranan yang penting sebab dengan adanya alat peraga ini bahan dengan mudah dapat dipahami oleh siswa. Alat peraga sering disebut audio visual, dari pengertian alat yang dapat diserap oleh mata dan telinga. Alat tersebut berguna agar pelajaran yang disampaikan guru lebih mudah dipahami oleh siswa. Dalam proses belajar mengajar alat peraga dipergunakan dengan tujuan membantu guru agar proses belajar siswa lebih efektif dan efisien.

Kelebihan dan kekurangan penggunaan alat peraga

Kelebihan penggunaan alat peraga yaitu:

1. Menumbuhkan minat belajar siswa karena pelajaran menjadi lebih menarik

2. Memperjelas makna bahan pelajaran sehingga siswa lebih mudah memahaminya

3. Metode mengajar akan lebih bervariasi sehingga siswa tidak akan mudah bosan 
4. Membuat lebih aktif melakukan kegiatan belajar seperti: mengamati, melakukan dan mendemonstrasikan dan sebagainya.

\section{Kekurangan alat peraga yaitu:}

1. Mengajar dengan memakai alat peraga lebih banyak menuntut guru

2. Banyak waktu yang diperlukan untuk persiapan

3. Perlu kesediaan berkorban secara materil

Adapun tujuan dari alat peraga adalah untuk:

1. Memperkenalkan, membentuk, memperkaya, serta memperjelas konsep pembelajaran.

2. Mengembangkan sikap yang dikehendaki.

3. Mendorong siswa lebih aktif dalam melakukan kegiatan.

Pemakaian alat peraga merangsang imajinasi anak dan memberikan kesan yang mendalam dalam mengajar, panca-indra dan seluruh kesanggupan seorang anak perlu dirangsang, digunakan dan libatkan, sehingga tak hanya mengetahui melainkan dapat memakai dan melakukan apa yang dipelajari.

Ada beberapa kelemahan sehubungan dengan gerakan pengajaran alat peraga itu, antara lain terlalu menekankan bahan-bahan peraganya sendiri dengan tidak menghiraukan kegiatan-kegiatan lain yang berhubungan dengan desain, pengembangan, produksi, evaluasi, dan pengelolaan bahan-bahan itu. Kelemahan lain adalah alat peraga dipandang sebagai "alat Bantu "semata-mata bagi guru dalam melaksanakan kegiatan mengajarnya sehingga keterpaduan antara bahan pelajaran dan alat peraga tersebut diabaikan. Disamping itu terlalu menekankan pentingnya materi ketimbang proses pengembangannya dan tetap memandang materi audiovisual sebagai alat Bantu guru dalam mengajar.

Proses pembelajaran dengan menggunakan bantuan alat peraga tidak selamanya dapat membuahkan hasil yang sesuai dengan yang diharapkan. Bahkan tidak tertutup kemungkinan digunakannya alat peraga justru bukannya membantu memperjelas konsep, akan tetapi sebaliknya misalnya membuat siswa menjadi bingung.

\section{Alat Peraga Model Pencernaan} Alat Dan Bahan

A. Alat:

1. Gunting Rautan

2. Pinsil,

3. Korek api,

4. Penggaris,

5. Stip

B. Bahan:
1. Lem Fox
2. pisau,
3. tripleks $60 \times 86 \mathrm{~cm}$,
4. selang transparan $5 / 8$ inci,
5. selang spiral 0,5 inci,
6. tutup botol round up,
7. balon,
8. bola plastik,

9. sarung pembersih closed,

10. botol bay cleen,

11. kertas karton,

12. lat profil bunga,

13. paku

14. lem alteco,

15. kabel tis,

16. lak ban

\section{Cara Pembuatan}

\section{Bahan A. Alat pencernaan}

1. Mulut di bentuk dengan menggunakan tutup botol roud up

2. Lambung.Untuk membentuk lambung:Dibentuk dengan menggabungkan 4 macam bahan bekas. Yaitu :Botol Bay clin + bola plastic + sarung pembersih closet dan dbungkus dengan balon

3. Mulut dan lambung di hubungkan dengan menggunakan selang transparan hingga membentuk usus halus

4. Selang spiral digunakan untuk membentuk usus besar

5. Dot kompeng bekas untuk membentuk anus

6. Semua alat yang sudah terbentu, dihubungkan satu dengan yang lainnya sehingga terbentuk rangkaian alat pencernaan .

7. Rangkaian alat pencernaan yang telah terhubung letakkan si atas karton, kemidian lem dengan lem fox

8. Untuk menguatkan posisi lambung,usus dan saluran pencernaan di perkuat dengan menggunakan kabel tis

9. Tempelkan alat peraga pencernaan yang sudah terbentuk di atas karton ke papan triplek dengan menggunakan lem alteco dan di perkuat dengan kabel tis

10. Setelah jadi, baru tempelkan nama nama bagian alat alat pencernaan yang sudah ditulis

11. Beri bingkai dan penyangga pada bagian belakangnya,

12. Alat peraga model pencernaan siap digunakan seperti pada Lembar Kerja Siswa

\section{Bahan B. Botol bercorong}

1. Botol bercorong terdiri dari 2 macam alat yaitu: botol aqua bekas + selang transparan .

2. Cara membuatnya:

Beri lubang pada bagian tutup botol aqua dengan menggunakan gunting

Masukkan selang transparan,

Agar tidak bocor beri sekeliling sambungan dengan lem alteco

Alat peraga siap digunakan seperti pada Lembar Kerja 


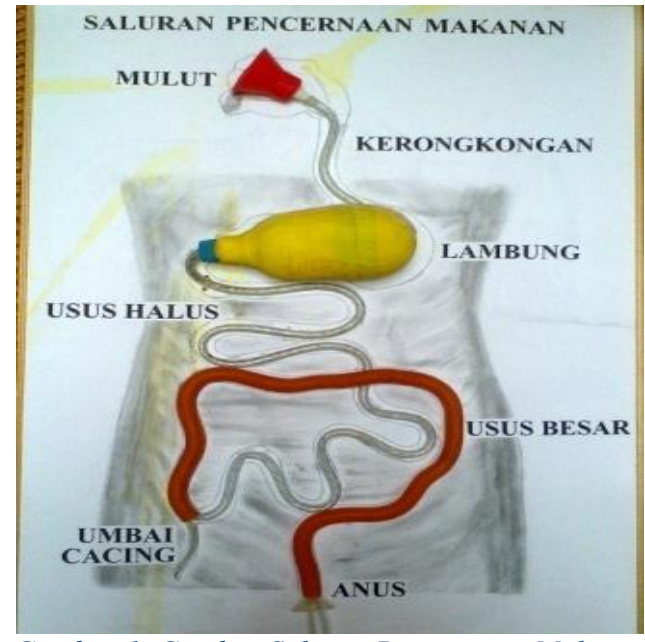

Gambar 1. Gambar Saluran Pencernaan Makanan

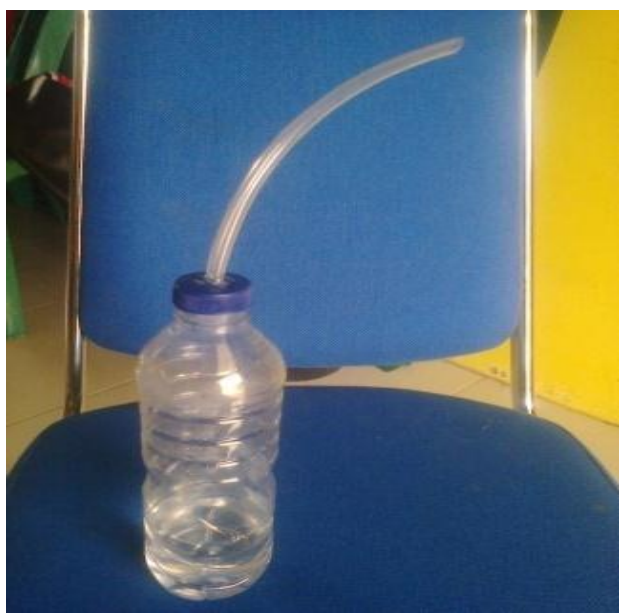

Gambar 2. Alat Peraga

\section{Hipotesa Tindakan}

Melalui tindakan menggunakan alat peraga model pencernaan dapat meningkatkan hasil belajar IPA terutama materi sistem pencernaan pada siswa kelas VIII Tuna daksa di SMPLB N Pembia Aceh Tamiang tahun ajaran $2015 / 2016$

\section{METODE PENELITIAN}

Penelitian dilakukan di dalam kelas atau Penelitian Tindakan Kelas.

Tempat penelitian adalah SMPLB Negeri Pembina Aceh Tamiang. Waktu penelitian pada semester I Tahun Pelajaran 2015/2016. Siklus I dilakukan pada 16 September 2015 dan Siklus II dilaksanakan pada 25 September 2015.

Sumber data ada sebanyak 1 orang siswa, yang terdiri 1 kelas, yaitu kelas VIII SMPLB Negeri Pembina Aceh Tamiang.

Instrumen yang digunakan sebagai pengumpul data hasil belajar siswa adalah :

a. Tes Awal (Pretes Siklus I dan Siklus II) yang diberikan sebelum proses pembelajaran b. Tes Akhir (Postes Siklus I dan Siklus II) yang diberikan setelah proses pembelajaran

c. Data pelaksanaan pembelajaran diperoleh dari hasil pengamatan teman observer selama pelaksanaan tindakan tiap siklus dengan menggunakan intrumen observasi

d. Data hasil pengamatan kegiatan siswa pada saat pembelajaran berikut

Data yang dianalisis meliputi hal hal sebagai

1. Perubahan yang terjadi pada siswa pada saat pembelajaran maupun setelah pembelajaran. Analisis yang digunakan adalah deskripsi, memaparkan data hasil pengamatan, pada lembar observasi guru dan siswa

2. Peningkatan hasil belajar setiap siklus Untuk mengetahui peningkatan hasil belajar digunakan analisis kuantitatif dengan rumus $\mathrm{P}=\frac{\text { Posrate-Baserate }}{\text { Baserate }} \times 100 \%$

\section{Keterangan}

$\mathrm{P}=$ Persentase peningkatan

Poserate $=$ nilai sesudah diberikan tindakan

Baserate $=$ nilai sebelum tindakan

Tolak ukur refleksi penelitian tindakan kelas ini adalah adanya peningkatan nilai, antusias, aktif, rasa senang, kelancaran dalam presentasi. Siswa secara siknifikan dalam pembelajaran IPA pada sistem pencernaan yang telah melebihi angka ketuntasan minimal.

Kiteria Ketuntasan Minimal di kelas VIII adalah nilai 65 . Siswa yang mendapat nilai 65 dikatakan tuntas

\section{Aeqradediłidutencernaan \\ B. Botol bercorong}

Pemecahan masalah secara bertahap melalui 2 siklus. Adapun tahapan kegiatan yang di lakukan oleh guru pada setiap siklus adalah :

1. Perencanaan (Planning)

2. Pelaksanaan Tindakan (Acting)

3. Observasi (Observation)

4. Analisis dan Planning (Reflekting)

\section{Siklus 1}

\section{a. Perencanaan}

1. Menyusun RPP Pada materi sistem pencernaan

2. Menyiapkan instrumen penelitian untuk guru dan siswa

3. penyiapkan lembaran soal pretes dan postes

4. Menyiapkan sumber belajar yang berupa materi Sistem pencernaan

5. Menentukan guru sebagai teman untuk melakukan observasi

6. Mengembangkan skenario pembelajaran

\section{b. Pelaksanaan}

1. Guru menanyakan kesiapan siswa,melakukan apersepsi ,motivasi untuk mengarahkan siswa memasuki materi sistem pencernaan 
2. Guru memotivasi untuk memperhatikan sumber belajar yaitu materi sistem pencernaan

3. Siswa diingatkan mempelajari tentang pencernaan mekanik dan pencernaan kimiawi,fungsi karbohidrat,protein ,lemak, gula,mineral ,dan vitamin

4. Kemudian guru mengamati dan membantu siswa menyelesaikan permasalahan

5. Guru menugaskan pada siswa untuk membuat rangkuman dari hasil kegiatan

6. Diakhir kegiatan guru melakukan tes akhir

\section{c. Observasi}

Setelah pelaksanaan kegiatan ,peneliti selanjutnya melakukan observasi terhadap pelaksanaan kegiatan dengan menggunakan lembar observasi .

Data yang dikumpulkan terdiri dari : (1) data kuantitas berupa hasil belajar setelah pelaksanaan kegiatan pembelajaran, (2) Observasi proses pembelajaran, (3) hasil pengamatan kegiatan siswa pada saat pembelajaran

\section{d. Refleksi}

Pada siklus 1 terlihat siswa belum aktif ,belum memanfaatkan waktu yang tersedia dengan tepat,siswa merasa kesulitan menggunakan LKS,sulit dalam membuat kesimpulan,pada saat presentasi terlihat siswa kurang ingat dan kurang percaya diri sehingga nilai belum memuaskan .Berdasarkan siklus I dapat disimpulkan untuk mencari alternatif untuk memecahkan masalah pada siklus ke II.

\section{Siklus 2}

Pelaksanaan proses pembelajaran pada siklus II dilakukan setelah adanya refleksi dari siklus I

\section{a. Perencanaan}

1. Menyusun RPP Pada materi sistem pencernaan

2. Menyiapkan instrumen penelitian untuk guru dan siswa

3. penyiapkan lembaran soal pretes dan postes

4. Menyiapkan sumber belajar yang berupa materi Sistem pencernaan

5. Menentukan guru sebagai teman untuk melakukan observasi

6. Mengembangkan skenario pembelajaran dengan alat peraga model sistem pencernaan,spidol,daftar nilai, absen siswa

\section{b. Pelaksanaan}

1. Guru menanyakan kesiapan siswa ,mengajak siswa berdo'a,mengisi daftar hadir,Kemudian membagikan lembar soal pretes

2. Kemudian Guru melakukan memulai pembelajaran dengan apersepsi ,motivasi untuk mengarahkan siswa memasuki materi sistem pencernaan

3. Guru memotivasi untuk memperhatikan sumber belajar yaitu materi sistem pencernaan

4. Siswa diingatkan mempelajari tentang makanan yang mengandung karbohidrat,fungsi lemak, mineral ,dan proses pencernaan
5. Guru membagikan LKS tentang proses pencernaan manusia

6. Kemudian guru mengamati dan membantu siswa untuk mengisi LKS

7. Guru menugaskan siswa untuk mempresentasikan hasil LKS.

8. Guru menugaskan pada siswa untuk membuat rangkuman dari hasil kegiatan

9. Diakhir kegiatan guru melakukan postes

\section{c. Observasi}

Setelah melakukan siklus II,peneliti selanjutnya melakukan observasi terhadap pelaksanaan kegiatan dengan Melakukan pengumpulan data dengan menggunakan lembar observasi .

Data yang dikumpulkan terdiri dari : (1) data kuantitas berupa hasil belajar setelah pelaksanaan kegiatan pembelajaran, (2) Observasi proses pembelajaran, (3) hasil pengamatan kegiatan siswa pada saat pembelajaran

\section{d. Refleksi}

Hasil yang di peroleh bersama rekan observer dikumpulkan dan dianalisis untuk memperoleh hasil sebagai refleksi.

1. Antusias siswa dalam mengikuti skenario pembelajaran,

2. Mudah dalam mengisi LKS

3. Pembelajarannya menarik, menyenangkan

4. Mudah dalam melakukan presentasi hasil LKS.

5. Dari siklus ke II disimpulkan bahwa siswa mencapai hasil $70 \%$.dalam proses pembelajaran sehingga kegiatan tidak dilanjutkan pada siklus berikutnya

\section{HASIL DAN PEMBAHASAN \\ Deskripsi Kondisi Awal}

Hambatan dalam melaksanakan proses pembelajaran dapat dipengaruhi oleh beberapa faktor diantaranya model dan media alat peraga yang digunakan oleh guru, kesesuaian penggunaan model dan media alat peraga dengan materi yang ingin disampaikan, Siswa sulit untuk berbicara di depan kelas

Berdasarkan data awal hasil belajar siswa kelas VIII Tuna Daksa tahun 2015 (pengalaman penulis,dengan memberikan soal UN IPA Tahun 2015). Yang hanya mendapat nilai 40. Hasil pencapaian nilai kelas VIII Tuna Daksa. tersebut tentu masih jauh dari nilai KKM yang di tetapkan yaitu angka 65 .

\section{Deskripsi Siklus I}

Kegiatan yang di lakukan pada tahap perencanaan meliput penyusun RPP pada KI Mendeskripsikan Sistem Pencernaan Manusia,menyiapkan instrumen penelitian untuk guru dan siswa,penyiapkan lembaran soal pretes dan 
postes,menyiapkan sumber belajar yang berupa materi untuk diskusi ,menentukan guru sebagai teman untuk melakukan observasi,mengembangkan skenario pembelajaran

Selanjutnya ketika peneliti melakukan proses pembelajaran guru menanyakan kesiapan siswa, memberikan soal pretes, kemudian melakukan apersepsi, motivasi untuk mengarahkan siswa memasuki materi sistem pencernaan,membagikan LKS, guru memotivasi untuk memperhatikan sumber belajar yaitu materi sistem pencernaan, siswa diingatkan mempelajari tentang makanan yang mengandung karbohidrat,fungsi lemak, mineral, dan alat pencernaan, guru menugaskan siswa untuk mempresentasikan hasil jawaban pada LKS, kedepan kelas, guru menugaskan pada siswa untuk membuat rangkuman dari hasil kegiatan diakhir kegiatan guru melakukan tes akhir.

Pada saat yang sama observer melakukan pengamatan dengan mengisi instrumen yang sudah disiapkan, yaitu lembar observasi pengamatan kegiatan guru dan siswa pada saat proses pembelajaran, dan hasil pengamatan kegiatan siswa pada saat pembelajaran.Hasil yang didapat dari angket kegiatan siswa pada saat pembelajaran adalah Antusias siswa dalam mengikuti proses pembelajaran, Kelancaran dalam mengemukakan ide dalam memecahkan masalah, Keaktifan siswa dalam proses pembelajaran, Keaktifan siswa dalam bertanya, Keaktifan siswa dalam mencari sumber belajar, Siswa senang dalam menjawab pertanyaan, Kelancaran siswa dalam melakukan presentasi,mendapat nilai kurang dengan rentang nilai < 60.

Melihat hasil angket diatas mendorong dilanjutkan pada siklus II.

\section{Deskripsi Siklus II}

Dalam perencanaan tindakan kelas ini peneliti telah menyusun perencanaan, menyusun RPP. Pada KI mendeskripsikan sistem pencernaan, menyiapkan instrumen penelitian untuk guru dan siswa, penyiapkan lembaran soal pretes dan postes, menyiapkan sumber belajar yang berupa materi Sistem pencernaan, menentukan guru sebagai teman untuk melakukan observasi, menyediakan alat peraga, menyiapkan lembar observasi guru dan siswa, angket hasil kegiatan pada saat pembelajaran, angket siswa setelah proses pembelajaran, KLS siswa.

Selanjutkan, ketika peneliti melakukan tindakan tahap ini, guru menanyakan kesiapan siswa, memberikan soal pretes, kemudian guru melakukan apersepsi, motivasi untuk mengarahkan siswa memasuki materi sistem pencernaan, membagikan LKS, kemudian membimbing dalam pengisian LKS, mengarahkan untuk memperhatikan sumber belajar yaitu materi sistem pencernaan, siswa diingatkan mempelajari tentang makanan yang mengandung karbohidrat, fungsi lemak, mineral, dan proses pencernaan, Guru menugaskan siswa untuk menjelaskan proses pencernaan, kemudian guru mengamati dan membantu siswadalam pengisian LKS, kemudian guru menugaskan siswa untuk mempresentasikan proses pencernaan kedepan kelas dengan menggunakan alat peraga model pencernaan, setelah guru menugaskan pada siswa untuk membuat rangkuman dari hasil kegiatan, dan diakhir kegiatan guru melakukan tes akhir

Pada sat yang sama, observer yang duduk pada bagian belakang melakukan pengamatan dengan mengisi instrumen yang sudah disiapkan yang terdiri dari: lembar observasi guru dan siswa, hasil pengamatan pengamatan kegiatan siswa pada saat pembelajaran. Hasil yang didapat dari hasil pengamatan : Dari angket kegiatan siswa pada saat pembelajaran adalah Antusias siswa dalam mengikuti proses pembelajaran, Kelancaran dalam mengemukakan ide dalam memecahkan masalah, Keaktifan siswa dalam proses pembelajaran, Keaktifan siswa dalam bertanya, Keaktifan siswa dalam mencari sumber belajar, Kelancaran siswa dalam menjawab pertanyaan, Kelancaran siswa dalam melakukan presentasi, mendapat nilai baik dengan rentang nilai $71-85$.

Sedangkan angket siswa setelah proses pembelajaran adalah Apakah pembelajaran menggunakan alat peraga dapat menyenangkan, Apakah pembelajaran menggunakan alat peraga membuat kamu mudah memahami pelajaran, Apakah pembelajaran menggunakan alat peraga membuat kamu berani mengemukakan pendapat, Apakah pembelajaran menggunakan alat peraga kamu lebih kreatif, Apakah kamu mengalami kesulitan, mendapat nilai sangat baik dengan capaian $100 \%$.

Sedangkan hasil postes pada siklus I dan II adalah seperti yang tertera pada tabel dibawah ini

Tabel 1. Nilai Kelas X Tuna Daksa

Tahun Pendidikan 2015 / 2016

\begin{tabular}{|c|l|c|c|c|}
\hline NO & NAMA & L/P & $\begin{array}{c}\text { Siklus } \\
\text { I }\end{array}$ & $\begin{array}{c}\text { Siklus } \\
\text { II }\end{array}$ \\
\hline 1 & Rizqi Yana & P & 40 & 68 \\
\hline & Jumlah & & 40 & 68 \\
\hline & Rata-rata & & $\mathbf{4 0}$ & $\mathbf{6 8}$ \\
\hline
\end{tabular}

Sumber Daftar Nilai Kelas X, 2015/2016

Melihat dari hasil pengamatan pada siklus II dapat dilihat ada kenaikan dan perubahan: kegiatan siswa pada saat pembelajaran didapat nilai baik dengan rentang nilai $71-85$, setelah proses pembelajaran 
mendapat nilai sangat baik dengan capaian $100 \%$,dan nilai hasil postes pada siklus I dan siklus II adalah,

$$
\mathrm{P}=\frac{\text { Posrate-Baserate }}{\text { Baserate }} \mathrm{X} 100 \%
$$

\section{Keterangan}

$\mathrm{P}=$ Persentase peningkatan

Poserate = nilai sesudah diberikan tindakan

Baserate $=$ nilai sebelum tindakan

Baik sekali $=86-100$

$$
\begin{aligned}
& \text { Baik } \quad=71-85 \\
& \text { Cukup } \quad=60-70 \\
& \text { Kurarang } \quad=>60
\end{aligned}
$$

Capaian persentasi peningkatan siswa adalah

$$
=\frac{68-40}{40} \times 100 \%=70
$$

Untuk mengetahui lebih jelas perubahandari siklus I ke siklus II, dapat dilihat pada tabel berikut

Tabel 2. Hasil pengamatan kegiatan siswa pada saat

\begin{tabular}{|c|c|c|c|c|}
\hline NO & Pertanyaan & Jawaban & $\begin{array}{l}\text { Siklus } \\
\text { I } \\
\%\end{array}$ & $\begin{array}{l}\text { Siklus } \\
\text { II } \\
\%\end{array}$ \\
\hline 1 & $\begin{array}{l}\text { Apakah } \\
\text { pembelajaran } \\
\text { menggunakan } \\
\text { alat peraga } \\
\text { dapat } \\
\text { menyenangkan? }\end{array}$ & $\begin{array}{l}\text { Ya } \\
\text { /Tidak }\end{array}$ & 0 & 100 \\
\hline 2 & $\begin{array}{l}\text { Apakah } \\
\text { pembelajaran } \\
\text { menggunakan } \\
\text { alat peraga } \\
\text { membuat kamu } \\
\text { mudah } \\
\text { memahami } \\
\text { pelajaran }\end{array}$ & $\begin{array}{l}\text { Ya } \\
\text { /Tidak }\end{array}$ & 0 & 100 \\
\hline 3 & $\begin{array}{l}\text { Apakah } \\
\text { pembelajaran } \\
\text { menggunakan } \\
\text { alat peraga } \\
\text { membuat kamu } \\
\text { berani } \\
\text { mengemukakan } \\
\text { pendapat? }\end{array}$ & $\begin{array}{l}\text { Ya } \\
\text { /Tidak }\end{array}$ & 0 & 100 \\
\hline 4 & \begin{tabular}{l}
\multicolumn{2}{l}{ Apakah } \\
pembelajaran \\
menggunakan \\
alat peraga \\
kamu lebih \\
kreatif?
\end{tabular} & $\begin{array}{l}\text { Ya } \\
\text { /Tidak }\end{array}$ & 0 & 100 \\
\hline 5 & $\begin{array}{l}\text { Apakah kamu } \\
\text { mengalami } \\
\text { kesulitan? }\end{array}$ & $\begin{array}{l}\text { Ya } \\
\text { /Tidak }\end{array}$ & 0 & 100 \\
\hline
\end{tabular}
pembelajaran

\begin{tabular}{|l|l|l|l|}
\hline No & $\begin{array}{l}\text { Kegiatan/ aspek } \\
\text { yang diamati }\end{array}$ & Siklus I & $\begin{array}{l}\text { Siklus } \\
\text { II }\end{array}$ \\
\hline 1 & $\begin{array}{l}\text { Antusias siswa dalam } \\
\text { mengikuti proses } \\
\text { pembelajaran }\end{array}$ & Kurang & $\begin{array}{l}\text { Baik } \\
\text { Sekali }\end{array}$ \\
\hline 2 & $\begin{array}{l}\text { Kelancaran dalam } \\
\text { mengemukakan ide } \\
\text { dalam memecahkan } \\
\text { masalah }\end{array}$ & Kurang & Kurang \\
\hline 3 & $\begin{array}{l}\text { Keaktifan siswa } \\
\text { dalam proses } \\
\text { pembelajaran }\end{array}$ & $\begin{array}{l}\text { Kurang } \\
\text { Keaktifan siswa } \\
\text { dalam bertanya }\end{array}$ & Kurang \\
\hline 5 & $\begin{array}{l}\text { Keaktifan siswa } \\
\text { dalam mencari } \\
\text { sumber belajar }\end{array}$ & Baik & Baik \\
\hline 6 & $\begin{array}{l}\text { Kelancaran siswa } \\
\text { dalam menjawab } \\
\text { pertanyaan }\end{array}$ & $\begin{array}{l}\text { Kelancaran siswa } \\
\text { dalam melakukan } \\
\text { presentasi }\end{array}$ & $\begin{array}{l}\text { Kaik } \\
\text { Sekali }\end{array}$ \\
\hline 7 & & Baik \\
\hline 4 & & \\
\hline
\end{tabular}

$\begin{array}{cll}\text { Keterangan: } & \text { Baik Sekali } & : 86-100 \\ & \text { Baik } & : 71-85 \\ & \text { Cukup } & : 60-70 \\ & \text { Kurang } & :>60\end{array}$

Tabel 3. Hasil angket siswa setelah proses pembelajaran

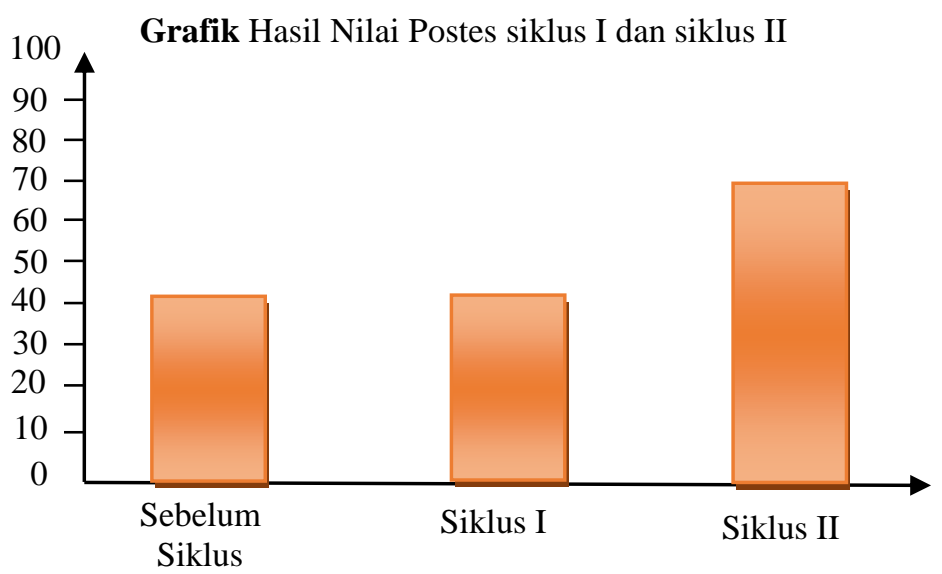

Pada grafik terlihat peningkatan hasil belajar pada siklus I yaitu 40, pada siklus II yaitu 68. Terjadi peningkatan $70 \%$. 
Hal ini menunjukkan bahwa pembelajaran dengan menggunakan alat peraga model pencernaan dapat meningkatkan pemahaman siswa pada materi sistem pencernaan manusia di SMPLB Negeri Pembina Aceh Tamiang

Kepada rekan rekan guru sangat dianjurkan agar mengajar pada sekolah berkebutuhan khusus menggunakan alat peraga model pencernaan dan mencipkan alat peraga pada materi ajar yang lain.Semoga Allah memberi kita kekuatan. Amin!

\section{PENUTUP}

Berdasarkan hasil penelitian diatas dapat disimpulkan bahwa:

1. Inovatif pembelajaran menggunakan alat peraga model pencernaan dapat menjadikan siswa lebik kreatif dalam pembelajaran

2. Keterampiulan menyampaikan pendapat kepada orang lain baik lisan maupun tulisan perlu adanya latihan

3. Inovatif pembelajaran menggunakan alat peraga model pencernaan dapat meningkatkan hasil prestasi belajar siswa.

Beberapa saran yang direkomendasikan dari hasil penelitian ini, yaitu:

1. Inovatif pembelajaran yang memacu pembelajaran berbasis siswa perlu dikembangkan guna meningkatkan kegiatan kegiatan belajar mengajar

2. Untuk mengembangkan sikap dan keterampilan bertanya,menyampaikan pendapat,menjawab,lisan dan tilisan memerlukan banyak latihan.

3. Guru perlu melakukan pendekatan kepada siswa untuk memberikan motivasi sehingga terbertuk rasa percaya diri

\section{DAFTAR PUSTAKA}

Agip Zainal. 2009. Penelitian Tindakan Kelas Untuk guru SMP, SMA dan SMK, Bandung: Yrama Widya

Amin dan Ina Yusuf Kesumah. 1991. Problematika Pendidikan Agama Islam Pada Anak Tuna Daksa Penyandang Tuna Daksa.Jakarta Rineke Cipta

Hamzah, B.Hamzah, dkk.2011. Belajar dengan Pendekatan PIALKEM. Jakarta.Bumi Aksara http://cacatanipa.blogspot.co.id/2015/06/siste m-pencernaan-pada-manusia.html https://www.google.co.id/search?q=anatomi+s istem + pencernaan + manusia\&espv $=2 \&$ biw $=$ $1024 \&$ bih $=494 \&$ source $=\operatorname{lnms} \&$ tbm $=$ isch\&s $\mathrm{a}=X \&$ sqi $=2 \& v e d=0$ ahUKEwjbk4TYz7XN AhWCj5QKHSx4AFoQ_AUIBigB\#tbm=is ch\&q=gambaran+sistem+pencernaan + man usia

Johnson,http://bpgupg.go.id/wi/bhndiklat/model model-pembelajaran.doc.

Sujana Nana 2006. Penilaian Hasil Proses Belajar Mengajar. Bandung: Remaja Rosdakarya.

Tim Abdi Guru. 2006. IPA Terpadu. Jakarta : Erlangga

Widarto,W., 1999, http://www.depdiknas.co.id (1999) 